UDC 618.19-006-089.87

DOI: $10.15587 / 2519-4798.2020 .209149$

\title{
ORGAN-SAVING AND RECONSTRUCTIVE PLASTIC SURGERY OF BREAST CANCER
}

\author{
T. Tamm, Yu. Vinnyk, V. Starikov, O. Prokopyuk, G. Oleynik, V. Vlasenko
}

Хірургічне лікування раку молочної залози є невід'ємною частиною комплексного лікування. В останні роки метою лікування є не тільки забезпечення тривалої безрецидивної та безметастатичної виживаності, але й належної якості життя, щзо вимагає нових підходів до оперативного втручання.

Метою дослідження був аналіз сучасних тенденцій розвитку методів хірургічного лікування молочної залози та шляхів поліпшення безпосередніх та відділених результатів.

Результати аналізу та ӥх обговорення. До останнього часу для лікування раку молочної залози здійснюється радикальна мастектомія, яка є причиною тривалих лімфовенозних ускладнень та значно погіршує якість життя пацієнток. В останні десятиріччя відбувається розвиток онкохірургії молочної залози в напрямку впровадження органозберігаючих та реконструктивно-пластичних операчій з удосконаленням технологї їх виконання. Загально-прийнятої конщепщії оптимального методу хірургічного лікування, як у відношенні обсягу операції, так і у виборі методу реконструкиії немає.

Висновки. Проблема вибору оптимального методу хірургічного лікування раку молочної залози, щьо має забезпечити онкологічний радикалізм та водночас гарний косметичний результат залишається не вирішеною та вимагає подальших досліджень

Ключові слова: рак молочної залози, хірургічне лікування, органозберігаючі операції, реконструкція молочної залози, якість життя

Copyright @ 0 2020, T. Tamm, Yu. Vinnyk, V. Starikov, O. Prokopyuk, G. Oleynik, V. Vlasenko.

This is an open access article under the CC BY license (http:///creativecommons.org/licenses/by/4.0).

\section{Introduction}

Breast cancer (BC) occupies a leading place in the structure of oncopathology in most countries of the world $[1,2]$. In Ukraine, BC is the most common tumor in women and ranks first in the structure of mortality from cancer [3]. An in-depth analysis of the molecular-genetic structure of $\mathrm{BC}$ allowed to develop new methods of systemic treatment, which allowed to achieve a significant improvement in the treatment of this pathology. But even at the present stage there is a fairly high frequency of recurrences and metastases, which in some forms of $\mathrm{BC}$ reaches $23 \%$ during a 10-year follow-up [4, 5].

The aim of the literature review was to analyze current trends in the development of methods of surgical treatment of the breast cancer and ways to improve immediate and long-term results.

\section{Basic methods of surgical treatment of breast} cancer

An integral part of the complex treatment of $\mathrm{BC}$ is surgery, which allows you to remove the main tumor and lymph nodes in the areas of locoregional distribution. Radical mastectomy (RM) is most often performed to ensure maximum removal of affected tissues and lymph nodes, which is the main method of preventing recurrence and metastasis. However, removal of the breast has negative consequences due to severe psycho-emotional trauma for a woman immediately after surgery and reduced quality of life in the future $[6,7]$. Therefore, in recent years, it has become increasingly important to achieve optimal aesthetic results without the loss of can- cer radicalism, which is especially important due to the increasing incidence of $\mathrm{BC}$ in young and middle-aged women [6].

The history of modern methods of surgical treatment of BC began in 1891, when W.S. Halsted suggested removal of the breast, large and small pectoral muscles, and lymph node dissection at levels 1-3 with a single breast block. Such "superradicalism" provided complete removal of the tumor and areas of potential metastasis, but led to the development of severe lymphostasis, chronic pain and dysfunction of the upper extremity. Therefore, in subsequent years, attempts to reduce the volume of the operation without losing radicalism did not stop. In this regard, the most important are the improvements proposed in 1948 by D. Patey and W. Dayson, which included a case of breast removal with a fascia of the pectoralis major muscle, pectoralis minor muscle and lymph dissection, and the method of J. L. Madden, proposed in 1965, with the preservation of both pectoral muscles, which in the second half of last century and at this time is performed most often [7]. Improvements in RM techniques have reduced the frequency and severity of lymphovenous and functional complications without significantly affecting the frequency of recurrences and metastases, but did not solve psychoemotional problems - reduced quality of life due to reduced self-esteem, attractiveness and sexuality with depression $[8,9]$.

Therefore, the further development of BC surgery took place in the direction of improving cosmetic results through the introduction of organ-preserving and reconstructive plastic surgery $[6,10,11]$. The development of 
these interventions was facilitated by the introduction of new methods of systemic therapy and methods of preoperative and intraoperative control of local lesions of breast tissue and regional lymph nodes. This approach was substantiated in the 1980 s by W. Veronesi, who emphasized the quality of life and suggested conservative BC surgery in the absence of sentinel lymph node involvement with rejection of RM in favor of quadrantectomy [12]. Subsequently, other organ-sparing operations were proposed, which differed in the amount of breast tissue removed (from minimal in tumorectomy to $1 / 4$ breast in radical resection) [13]. In addition, methods have been proposed to preserve the skin and nipple-areolar complex and further facilitate the reconstruction of the breast $[14,15]$. In recent years, endoscopic methods of subcutaneous mastectomy have been proposed, which can significantly reduce the trauma of the operation and preserve the contours of the breast [16-18].

\section{Breast reconstruction}

Another way to improve the cosmetic results of surgery for BC is reconstructive plastic surgery. Restoration of the natural size and shape of the breast is considered an important component of women's rehabilitation after surgery and is considered a method of prevention and treatment of mental disorders [19-21].

Their own tissues and/or artificial materials - endoprostheses are used for the reconstruction of the breast. Muscle-skin flaps on the feeding vascular leg are most often used for autotransplantation: with m. latissimus dorsi (LDM flap), with $\mathrm{m}$. transverse rectus abdominis (TRAM-flap), rarely deep perforated and superficial lower-epigastric flaps [22, 23]. Autologous fat is also used to correct the defect of the tissues of the axillary region and breast $[24,25]$. However, these methods are quite complex and are characterized by a fairly high frequency of postoperative complications, which are observed in more than $25 \%$ of patients [26].

More often, breast reconstruction is performed using alloplastic materials, which allow to obtain good cosmetic results, but technically less complex [19-21]. The development of this area of breast augmentation is provided by both the improvement of endoprostheses and its improvement of implantation techniques. Implants are proposed that differ in surface structure, shape and type of filler, which allows you to choose the implant as close as possible to the natural shape of the breast and the density of its tissue [27].

The main methods of breast reconstruction are one-stage implantation of an endoprosthesis in a prepared skin pocket after skin-preserving ME and twostage implantation - preparation of a skin pocket with an expander in the first stage followed by implantation of an endoprosthesis (in 4-6 months). In addition, a permanent expander is used, which is both an implant consisting of two pantries: one is filled with saline and provides gradual stretching of the skin, the other - silicone, which gives shape and density [7,28].

The main argument of supporters of one-stage breast reconstruction is the reduction of rehabilitation time with a relatively small number of postoperative complications [29]. But this method requires saving the skin to form a pocket, and has several contraindications. In addition, primary reconstruction contributes to the development of complications from the implant when using neoadjuvant and adjuvant radiation therapy in combination with chemotherapy [30]. The frequency of such complications reaches $58.3 \%$ [31]. It was found that radiation therapy in the presence of an implant increased the frequency of its loss by 4 times and increased the risk of severe capsular contracture [32]. Two-stage breast reconstruction is considered less complicated and less traumatic and is especially appropriate if postoperative radiation therapy is required $[33,34]$.

In addition, the use of additional materials to cover the endoprosthesis and the formation of submammary folds helps to improve the results of breast arthroplasty. Synthetic meshes [34], acellular dermal matrix [33] and the lower deepithelialized flap of the breast created during surgery are used for this purpose $[35,36]$. Also, it should be noted that the optimal cosmetic result involves achieving symmetry of the breast. This is ensured not only by breast augmentation after surgery, but also by corrective surgery on a healthy breast [37].

At present, the need to achieve optimal oncological and aesthetic results is beyond doubt. Therefore, there are more and more reports of an increase in the frequency of organ-saving and reconstructive surgeries. For example, in Denmark, breast reconstruction is performed in $14 \%$ of mastectomies [38], in the UK - in $21 \%$ of cases [39]. In Korea, along with an increase in the number of breast reconstructions, there is a decrease in the frequency of PME in favor of organ-sparing operations (from $61.3 \%$ to $32.3 \%$ ) [40].

The immediate and long-term results of BC surgical treatment also depend on the development of specific complications due to lymphovenous outflow disorders after lymph dissection [41]. Prolonged lymphorrhea, postmastectomy syndrome, inflammation and impaired wound healing are the most common [42, 43]. To prevent these complications, various methods of hemostasis and lymphostasis, wound drainage and postoperative management have been proposed [44, 45]. Research in this direction does not stop.

\section{Conclusions}

Thus, the modern development of BC oncosurgery is characterized by a combination of oncological radicalism and optimal cosmetic results, which can ensure good survival and quality of life of patients. Modern methods of systemic therapy, even in the presence of invasive forms of BC can achieve good results in the implementation of organ-saving operations. But still in many cases RM is the operation of choice. In these cases and in other operations that lead to permanent deformation of the breast, the main method of prevention of psycho-emotional disorders and ensuring a proper quality of life are reconstructive plastic surgery. 
The immediate and long-term results of these operations are ambiguous. Each of the methods has arguments "pro" and "con", and the choice of one or another method depends on the characteristics of the underlying disease, the experience of the surgeon, the practice and the desire of the patient. The introduction of new and improved methods of surgical interventions and postoperative rehabilitation of patients is a promising area of BC oncology surgery.

\section{Contribution of authors}

The contribution of each author to this work is the same. All authors have read and approved the final version of the manuscript.

\section{Conflict of interest}

The authors declare that they have no conflicts of interest.

\section{References}

1. Global, regional, and national life expectancy, all-cause mortality, and cause-specific mortality for 249 causes of death, 1980-2015: a systematic analysis for the Global Burden of Disease Study 2015 (2016). Lancet, 388, 1459-1544. Available at: http:// www.thelancet.com/pdfs/journals/lancet/PIIS0140-6736(16)31012-1.pdf

2. Ghoncheh, M., Pournamdar, Z., Salehiniya, H. (2016). Incidence and Mortality and Epidemiology of Breast Cancer in the World. Asian Pacific Journal of Cancer Prevention, 17 (sup3), 43-46. doi: http://doi.org/10.7314/apjcp.2016.17.s3.43

3. Fedorenko, Z. P., Hulak, L. O., Mykhailovych, Yu. Y., Horokh, Ye. L., Ryzhov, A. Yu., Sumkina, O. V. et. al. (2018). Rak v Ukraini, 2016-2017. Zakhvoriuvanist, smertnist, pokaznyky diialnosti onkolohichnoi sluzhby. Biuleten natsionalnoho kantser-reiestru Ukrainy. Kyiv, 19. Available at: http://www.ncru.inf.ua/publications/BULL_19/index.htm

4. Zikiryakhodzhayev, A. D., Rasskazova, E. A., Tukmakov, A. Y., Shirokikh, I. M. (2019). Relapses after radical subcutaneous/skin-sparing mastectomy with simultaneous reconstruction in breast cancer. Research'n Practical Medicine Journal, 6 (1), $33-40$. doi: http://doi.org/10.17709/2409-2231-2019-6-1-3

5. Holleczek, B., Stegmaier, C., Radosa, J. C., Solomayer, E.-F., Brenner, H. (2019). Risk of loco-regional recurrence and distant metastases of patients with invasive breast cancer up to ten years after diagnosis - results from a registry-based study from Germany. BMC Cancer, 19 (1). doi: http://doi.org/10.1186/s12885-019-5710-5

6. Solodkii, V. A., Sherstneva, T. V., Meskikh, E. V., Izmailov, T. R. (2018). The state of the issue of reconstructive plastic surgery for breast cancer in the Russian Federation and in the world. Vestnik Nacionalnogo mediko-khirurgicheskogo Centra im. N. I. Pirogova, 13 (3), 132-137. doi: http://doi.org/10.25881/BPNMSC.2018.78.94.028

7. Malygin, S. E. (2015). The role of mastectomy in treatment and prophylaxis of breast cancer: beginning, evolution and recent changes. Malignant Tumours, 4, 3-13. doi: http://doi.org/10.18027/2224-5057-2015-4-3-13

8. Aerts, L., Christiaens, M. R., Enzlin, P., Neven, P., Amant, F. (2014). Sexual functioning in women after mastectomy versus breast conserving therapy for early-stage breast cancer: A prospective controlled study. The Breast, 23 (5), 629-636. doi: http:// doi.org/10.1016/j.breast.2014.06.012

9. Urban, C., Anselmi, K. F., Kuroda, F., Schwartz, J.-C. (2014). Oncoplasty as the Standard of Care in Breast Cancer Surgery. European Oncology \& Haematology, 10 (1), 43-47. doi: http://doi.org/10.17925/eoh.2014.10.1.43

10. Galich, S. P., Pinchuk, V. D. (2011). Rekonstruktivnaia khirurgiia grudi. Kyiv: Kniga-plius, 264.

11. Sobolevskii, V. A., Ivashkov, V. Iu., Mekhtieva, N. I. G. (2017). Reconstructive and plastic surgery for breast cancer. Prakticheskaia onkologiia, 18 (3), 246-255. Available at: https://practical-oncology.ru/articles/593.pdf

12. Watts, G. (2016). Umberto Veronesi. The Lancet, 388 (10060), 2600. doi: http://doi.org/10.1016/s0140-6736(16)32230-9

13. Zikiriakhodzhaev, A., Rasskazova, E. (2015). Organ-sparing surgery for breast cancer. Vrach, 6, 40-42. Available at: http:// onco.rusvrach.ru/archive/25877305-2015-06-13.pdf

14. Maxwell, G. P., Storm-Dickerson, T., Whitworth, P., Rubano, C., Gabriel, A. (2011). Advances in Nipple-Sparing Mastectomy: Oncological Safety and Incision Selection. Aesthetic Surgery Journal, 31 (3), 310-319. doi: http://doi.org/10.1177/ 1090820x11398111

15. Kinoshita, S., Kyoda, S., Hirano, A., Akiba, T., Nojima, K., Uchida, K. et. al. (2013). Clinical comparison of four types of skin incisions for skin-sparing mastectomy and immediate breast reconstruction. Surgery Today, 44 (8), 1470-1475. doi: http:// doi.org/10.1007/s00595-013-0722-2

16. Lai, H.-W., Wu, H.-S., Chuang, K.-L., Chen, D.-R., Chang, T.-W., Kuo, S.-J. et. al. (2014). Endoscopy-assisted total mastectomy followed by immediate pedicled transverse rectus abdominis musculocutaneous (TRAM) flap reconstruction: preliminary results of 48 patients. Surgical Innovation, 22 (4), 382-389. doi: http://doi.org/10.1177/1553350614546003

17. Lai, H.-W., Chen, S.-T., Chen, D.-R., Chen, S.-L., Chang, T.-W., Kuo, S.-J. et. al. (2016). Current Trends in and Indications for Endoscopy-Assisted Breast Surgery for Breast Cancer: Results from a Six-Year Study Conducted by the Taiwan Endoscopic Breast Surgery Cooperative Group. PLOS ONE, 11(3), e0150310. doi:10.1371/journal.pone.0150310

18. Tukenmez, M., Ozden, B. C., Agcaoglu, O., Kecer, M., Ozmen, V., Muslumanoglu, M., Igci, A. (2014). Videoendoscopic Single-Port Nipple-Sparing Mastectomy and Immediate Reconstruction. Journal of Laparoendoscopic \& Advanced Surgical Techniques, 24 (2), 77-82. doi: http://doi.org/10.1089/lap.2013.0172

19. Bit-Sava, E. M., Egorenkov, V. V., Damenia, A. O., Melnikova, O. A., Akhmedov, R. M., Monogarova, M. A. et. al. (2017). New approaches in breast cancer surgery. Practical Oncology, 18 (3), 232-245. doi: http://doi.org/10.31917/1803232

20. Ermoshchenkova, M. V., Chissov, V. I., Usov, A. V., Sukhotko, A. S., Tukmakov, A. Y., Baichorov, E. A., Zikiryahodjaev, A. D. (2017). Biological and synthetic mesh use in reconstructive surgery in patients with breast cancer. Research'n Practical Medicine Journal, 4 (1), 23-32. doi: http://doi.org/10.17709/2409-2231-2017-4-1-3 
21. Franceschini, G., Martin, S. A., Di Leon, A., Magno, A., Moschella, F., Accetta, C., Masetti, R. (2015). New trends in breast cancer surgery: a therapeutic approach increasingly efficacy and respectful of the patient. Giornale di Chirurgia - Journal of Surgery, 36 (4), 145-152. doi: http://doi.org/10.11138/gchir/2015.36.4.145

22. Hernanz, F., Sánchez, S., Cerdeira, M. P., Figuero, C. R. (2011). Long-term results of breast conservation and immediate volume replacement with myocutaneous latissimus dorsi flap. World Journal of Surgical Oncology, 9 (1). doi: http://doi.org/10.1186/14777819-9-159

23. Wang, X.-L., Liu, L.-B., Song, F.-M., Wang, Q.-Y. (2014). Meta-analysis of the Safety and Factors Contributing to Complications of MS-TRAM, DIEP, and SIEA Flaps for Breast Reconstruction. Aesthetic Plastic Surgery, 38 (4), 681-691. doi: http:// doi.org/10.1007/s00266-014-0333-3

24. Simonacci, F., Bertozzi, N., Grieco, M. P., Grignaffini, E., Raposio, E. (2016). Autologous fat transplantation for breast reconstruction: A literature review. Annals of Medicine and Surgery, 12, 94-100. doi: http://doi.org/10.1016/j.amsu.2016.11.012

25. Van Turnhout, A. A., Fuchs, S., Lisabeth-Broné, K., Vriens-Nieuwenhuis, E. J. C., van der Sluis, W. B. (2017). Surgical Outcome and Cosmetic Results of Autologous Fat Grafting After Breast Conserving Surgery and Radiotherapy for Breast Cancer: A Retrospective Cohort Study of 222 Fat Grafting Sessions in 109 Patients. Aesthetic Plastic Surgery, 41 (6), 1334-1341. doi: http:// doi.org/10.1007/s00266-017-0946-4

26. Zikiryakhodzhaev, A. D., Efanov, V. V., Usov, F. N., Ismailova, M. M. (2015). Complications of delayed reconstructive and plastic surgery after radical mastectomy. Tumors of Female Reproductive System, 11 (2), 31-34. doi: http://doi.org/10.17650/19944098-2015-11-2-31-34

27. Maxwell, G. P., Gabriel, M. (2017). Breast implant design. Gland Surgery, 6 (2), 148-153. doi: http://doi.org/10.21037/ gs.2016.11.09

28. Zikiryakhodzhaev, A. D., Shirokikh, I. M., Ablitsova, N. V., Ermoshchenkova, M. V., Kharchenko, N. V., Saribekyan, E. K. et. al. (2018). Biological and synthetic materials in reconstructive surgery for breast cancer treatment (literature review). Tumors of Female Reproductive System, 14 (1), 28-37. doi: http://doi.org/10.17650/1994-4098-2018-14-1-28-37

29. Dragun, A. E., Huang, B., Tucker, T. C., Spanos, W. J. (2012). Increasing Mastectomy Rates Among all Age Groups for Early Stage Breast Cancer: A 10-Year Study of Surgical Choice. The Breast Journal, 18 (4), 318-325. doi: http://doi.org/10.1111/j.15244741.2012.01245.x

30. Ho, A. L., Bovill, E. S., Macadam, S. A., Tyldesley, S., Giang, J., Lennox, P. A. (2014). Postmastectomy Radiation Therapy after Immediate Two-Stage Tissue Expander/Implant Breast Reconstruction. Plastic and Reconstructive Surgery, 134 (1), 1e-10e. doi: http://doi.org/10.1097/prs.0000000000000292

31. Khailenko, D. V., Egorov, Iu. S., Portnoi, S. M., Khailenko, V. A. (2016) Primary reconstructive plastic surgery in nodular form of III stage breast cancer. Rossiiskii onkologicheskii zhurnal, 21 (4), 175-178.

32. Cordeiro, P. G., Albornoz, C. R., McCormick, B., Hu, Q., Van Zee, K. (2014). The impact of postmastectomy radiotherapy on two-stage implant breast reconstruction: an analysis of long-term surgical outcomes, aesthetic results, and satisfaction over 13 years. Plastic and Reconstructive Surgery, 134 (4), 588-595. doi: http://doi.org/10.1097/prs.0000000000000523

33. Nahabedian, M. Y., Jacobson, S. R. (2019). Two-stage prepectoral breast reconstruction. Gland Surgery, 8 (1), 43-52. doi: http://doi.org/10.21037/gs.2018.09.04

34. Casella, D., Di Taranto, G., Marcasciano, M., Lo Torto, F., Barellini, L., Sordi, S. et. al. (2019). Subcutaneous expanders and synthetic mesh for breast reconstruction: Long-term and patient-reported BREAST-Q outcomes of a single-center prospective study. Journal of Plastic, Reconstructive \& Aesthetic Surgery, 72 (5), 805-812. doi: http://doi.org/10.1016/j.bjps. 2018.12.018

35. Hon, H. H., Mubang, R. N., Wernick, B. D., Freedman, S. F., Stoltzfus, J. C., Miele, L. F. et. al. (2017). Acellular dermal matrix versus inferior deepithelialized flap breast reconstruction: equivalent outcomes, with increased cost. Plastic and Reconstructive Surgery - Global Open, 5 (6), e1382. doi: http://doi.org/10.1097/gox.0000000000001382

36. Sorkin, M., Qi, J., Kim, H. M., Hamill, J. B., Kozlow, J. H., Pusic, A. L., Wilkins, E. G. (2017). Acellular dermal matrix in immediate expander/implant breast reconstruction: a multicenter assessment of risks and benefits. Plastic and Reconstructive Surgery, 140 (6), 1091-1100. doi: http://doi.org/10.1097/prs.0000000000003842

37. Zikiryahodzhaev, A. D., Rasskazova, E. A. (2018). Two-stage delayed reconstruction in patients with breast cancer after mastectomy. Malignant Tumours, 8 (2), 43-49. doi: http://doi.org/10.18027/2224-5057-2018-8-2-43-49

38. Hvilsom, G. B., Hölmich, L. R., Frederiksen, K., Steding-Jessen, M., Friis, S., Dalton, S. O. (2010). Socioeconomic position and breast reconstruction in Danish women. Acta Oncologica, 50 (2), 265-273. doi: http://doi.org/10.3109/0284186x.2010.529823

39. Thiruchelvam, P. T. R., McNeill, F., Jallali, N., Harris, P., Hogben, K. (2013). Post-mastectomy breast reconstruction. BMJ, 347 (2), f5903-f5903. doi: http://doi.org/10.1136/bmj.f5903

40. Park, E. H., Min, S. Y., Kim, Z., Yoon, C. S., Jung, K.-W. et. al. (2017). Basic Facts of Breast Cancer in Korea in 2014: The 10-Year Overall Survival Progress. Journal of Breast Cancer, 20 (1), 1. doi: http://doi.org/10.4048/jbc.2017.20.1.1

41. Nguyen, T. T., Hoskin, T. L., Habermann, E. B., Cheville, A. L., Boughey, J. C. (2017). Breast Cancer-Related Lymphedema Risk is Related to Multidisciplinary Treatment and Not Surgery Alone: Results from a Large Cohort Study. Annals of Surgical Oncology, 24 (10), 2972-2980. doi: http://doi.org/10.1245/s10434-017-5960-x

42. Madsen, R. J., Esmonde, N. O., Ramsey, K. L., Hansen, J. E. (2016). Axillary Lymph Node Dissection Is a Risk Factor for Major Complications After Immediate Breast Reconstruction. Annals of Plastic Surgery, 77 (5), 513-516. doi: http://doi.org/10.1097/ sap.0000000000000653 
43. Marinescu, S. A., Bejinariu, C. G., Şapte, E., Marinaş, M. C., Giuglea, C. (2019). Complications related to breast reconstruction after mastectomy using multiple surgical techniques - a national and international comparative analysis. Romanian Journal of Morphology and Embryology, 60 (1), 87-93.

44. Gambardella, C., Clarizia, G., Patrone, R., Offi, C., Mauriello, C., Romano, R. et. al. (2019). Advanced hemostasis in axillary lymph node dissection for locally advanced breast cancer: new technology devices compared in the prevention of seroma formation. BMC Surgery, 18 (S1). doi: http://doi.org/10.1186/s12893-018-0454-8

45. Vinnyk, Y. O., Vlasenko, V. G., Baranova, A. V. (2019). Prophylaxis of complications after radical operations in patients, suffering a mammary gland cancer. Klinicheskaia Khirurgiia, 86 (11-12), 46-50. doi: http://doi.org/10.26779/25221396.2019.11-12.46

Received date 20.05.2020

Accepted date 16.06.2020

Published date 31.07.2020

Tamara Tamm, MD, Professor, Department of Surgery and Proctology, Kharkiv Medical Academy of Postgraduate Education, Amosova str., 58, Kharkiv, Ukraine, 61176

E-mail: tamm_ti@ukr.net

Yuri Vinnyk, MD, Professor, Head of Departmen, Department of Oncology Surgery, Radiation Therepy, Palliative Care, Kharkiv Medical Academy of Postgraduate Education, Amosova str., 58, Kharkiv, Ukraine, 61176

E-mail: profvinnik@gmail.com

Volodimir Starikov, MD, Professor, Department of Oncology, Kharkiv National Medical University, Nauky ave., 4, Kharkiv, Ukraine, 61022

Oleksandra Prokopyuk, PhD, Associate Professor, Department of Obstetrics, Gynecology and Oncology, Kharkiv Medical Academy of Postgraduate Education, Amosova str., 58, Kharkiv, Ukraine, 61176 E-mail: prokopyuka@gmail.com

Grigory Oleynik, MD, Professor, Department of Combustiology, Reconstructive and Plastic Surgery, Kharkiv Medical Academy of Postgraduate Education, Amosova str., 58, Kharkiv, Ukraine, 61176

E-mail: Griol54@meta.ua

Vadym Vlasenko, PhD, Molecule Medical Center, Hoholia str., 7, Kharkiv, Ukraine, 61057

E-mail: oncoplast@i.ua 